Journal of CORPORATE RESPONSIBILITY

AND LEADERSHIP

InNOVATIONS IN CORPORATE SOCIAL RESPONSIBILITY

and Public Management

\title{
Rise and Decline of the Welfare State: The Swedish Case as a Solution
}

DOI: http://dx.doi.org/10.12775/JCRL.2018.021

\section{Sergio Luis NÁÑEZ Alonso}

Social and Legal Sciences Faculty, Catholic University Santa Teresa de Jesús of Ávila, Spain e-mail: sergio.nanez@ucavila.es

\section{RICARDO REIER FORRADELLAS}

Social and Legal Sciences Faculty, Catholic University Santa Teresa de Jesús of Ávila, Spain e-mail: ricardo.reier@ucavila.es

\begin{abstract}
Purpose: This article analyses the unsustainability of the welfare state. This unsustainability is not caused by a financial crisis, but is caused by its own design and initial conception. For this, the case of Sweden is shown as an example; and the policies adopted by this Nordic country to correct the unsustainability of the welfare state mentioned above.

Design/methodology/approach: The applied methodology has been, on the one hand, a literary review of the welfare state concept. On the other hand, an analysis has been carried out with various economic indicators that serve to corroborate the aforementioned unsustainability and the effect of the decisions taken by Sweden.

Research and practical limitations/implications: The analysis of economic variables such as GDP or the collection of taxes on GDP is burdened with the classical limitation on the cause-effect relationship. The problem of causality in economics is one of the most significant in the discipline. This problem is fundamental in historical analyses, when it comes to relating a phenomenon that has occurred with the causes that generated it.
\end{abstract}


Originality: The debate about the welfare state and its sustainability is gaining strength from very different spheres. In an unstable and highly globalised economic environment, the role that states must play in the economy is being reformulated. The present paper analyses the development and growth of the welfare state as one of the differential elements of the developed economies (especially in the Western European area), and its subsequent crisis and loss of legitimacy due to its financial unsustainability.

Findings: This article shows how the introduction of private companies that provide public services can be a solution to the welfare state crisis. For this, the Swedish case is used as an example. In the Nordic country, it was found that the introduction of private companies in the provision of public services has not reduced social assistance services or their quality. What is important, it has been a new competitive management, which guarantees the quality of the services provided, at a lower cost to the public sector budget.

Paper type: theoretical paper.

Keyords: welfare state, crisis of welfare state, Swedish model, civil society.

\section{Introduction}

The generalisation in the application of interventionist policies by the governments in most of the developed countries of the Western world, especially after the end of the Second World War, has helped to define the economic, political and social reality of these countries. The political sociologist and German professor Claus Offe indicates, referring to the welfare state, that "the set of state institutions and practices to which this concept refers has been developed in Western capitalism since the Second World War" (Offe, 2007, p. 109). The welfare state has been one of the main protagonists in the economic, social and political analysis of the economies of developed countries (especially European ones) in recent years. Many are the authors who have studied the welfare state from very different areas. Like almost all concepts of political roots, the one of the welfare state is necessarily imprecise (Muñoz Machado, García Delgado and González Seara, 1997). We are trying to delimit a concept that has an imprecise and mutable content (Jiménez Franco, 2000). Although its origin is diffuse, its appearance is usually linked to a series of concepts related to overcoming deviations from the capitalism and the own deficiencies of the liberal bourgeois state, 
whose material conceptions appear to be definitive in crisis after the First World War (Jiménez Franco, 2000). In this way, the concept can be related to an increase in interventionism boosted by events such as "the First World War, the Russian Revolution of 1917, the Great Depression of 1929 or the doctrinal impact of Keynesianism" (Domingo Solans, 1998, p. 11). However, it is possible to review some historical background that has served to modulate and define the development towards the current concept of the welfare state.

The aim of the paper is to analyse the unsustainability of the welfare state. This unsustainability is not caused by a financial crisis, but is caused by its own design and initial conception. For this, the case of Sweden is shown as an example, and the policies adopted by this Nordic country to correct the unsustainability of the welfare state mentioned above. The method of study employed to achieve the aim of the paper is a literature review of the welfare state on the one hand. On the other hand, an analysis has been carried out with various economic indicators that serve to corroborate the aforementioned unsustainability and the effect of the decisions taken by Sweden. First, a historical vision of the welfare state and the proposed models is presented. Then, the crisis that has suffered the welfare state concept and its unsustainability is analysed in order to present the actions taken by Sweden as an example. The study leads to some conclusions drawn from the Swedish experience.

\section{History of welfare state models}

\subsection{Social Insurance of Otto Von Bismarck, 1884: Germany}

The first stage of the Industrial Revolution carried out in the nineteenth century resulted in, among other consequences, the implementation of nefarious living conditions for the great mass of workers, generating the emergence of a new social class: the working class. There was observed a massive exodus of workers and their families from the countryside to the city with the disappearance, in addition, of a large number of manual jobs due to the rapid and growing process of industrialisation. This change in social organisation caused, among other things, a drop in the salary level, an increase in working hours, illnesses due to lack of hygiene and, in general, terrible working conditions. This gradual exodus from rural to urban life was a dislocation in many families who 
lost their usual means of protection from old age and disease. It is in the face of this new order that the need to arbitrate, initially from the administrations closest to the citizen and later from the state, new elements of protection for the new industrial workers before the new needs of social coverage became evident. Otto Von Bismark was a pioneer in these aspects (in Germany in 1884) with the implementation of social insurance. Friedrich von Hayek, in his book Der Weg zur Knechtschaft, places the origins of the welfare state in Bismark's policies, indicating that the Anglo-Saxon expression welfare state is a translation of the expression used in Germany in the $19^{\text {th }}$ century "where, in contrast to the traditional State of Police - Polizeistaat, the term State of Welfare Wohlfahrstaat, and before that of welfare police - Wohlfahrpolizei was coined" (Hayek, 1946, p. 5). Bismark, with the social legislation of the eighties of the nineteenth century, implemented a new concept of public social service that was exemplary and pioneering for the rest of the world (Mommsen, 1996, p. 172). This social legislation included three protection insurance aspects i.e. a public health insurance in 1883, an accident insurance in 1884, and pensions for disability and retirement, in 1889, and forced the contribution of economic resources by three sectors: the company, the workers themselves and the state, that it would act not only as a financing party but also as the administrator of the new system. In this way, the social legislation introduced by Bismark led to the emergence of what became known as the new welfare state.

\subsection{The National Institute of Forecast, 1908: Spain}

Under the influence of the German initiative, then the Minister of Home Office Eduardo Dato founded the National Institute of Welfare in 1908 and was responsible for incorporating the social aspects in the form of law that resulted in the development of the General Law of Accidents, 1900, the Institute of Social Reforms in 1903, and the Labor Inspection in 1907 (Martínez Girón, 2001). The Institute of Social Welfare was in charge of cataloging and quantifying the economic benefits to which the worker and his family were entitled in case of death or disability as a consequence of work accidents. In the same way, occupational hygiene started to be regulated incipiently in the workplace and workers were encouraged to contract voluntary insurance, both for old age and for sickness. Subsequently, the state itself was expanding social protection, which was financed not only with the contributions of those 
affected but with increasing contributions from the state charged to tax revenues (Rosete, 2004).

\subsection{The Social Security Act, 1935: The United States}

A change of enormous importance in relation to public social policies arised when on June 8, 1934, President Franklin D. Roosevelt announced in a message to the Congress his intention to establish a general program of social security in the United States of America. Thus, the Social Security Act was signed and came into law on August 14, 1935. This law, in addition to including several aspects of general welfare, included a social security program designed to pay a continuous income after retirement to those retired workers who are sixty-five years old or older. Originally, the law referred only to retirement benefits and only those related to the worker himself. Subsequently, the amendments to the law introduced in 1939 implied an important change in the Social Security program. Two benefit categories were added i.e. payments to the wife and children of a retired worker (what are called dependent benefits) and benefits of survivors in case of the premature death of the worker (Social Security Administration, 2015). These amendments transformed Social Security in the United States of America, which shifted from being an individual retirement program to an economic security program that included the worker's family.

\subsection{Lord Beveridge Report, 1942: The United Kingdom}

Finally, the founding act of the modern welfare state was framed in the United Kingdom, in the middle of the Second World War, with the famous Report to the Parliament on Social Insurance and Allied Services drafted by Baron William Beveridge ${ }^{1}$, at the request of the then Minister of Health and Care Ernest Bevin, made public in November 1942. The Beveridge Report constituted an important change in

${ }^{1}$ William Henry Beveridge (1879-1963), first Baron of Tuggal. A British economist, he worked on research focused on the problems of unemployment and the welfare state and, after the publication of the Social Insurance and Allied Services report in 1942 (later known as the Beveridge Report), he was recognized as a pioneer in the development of modern welfare systems. Other fundamental works of Beveridge were Unemployment: A Problem of Industry of 1909 and Full Employment in a Free Society of 1944. 
the social security model, giving it a comprehensive and universal character (Ordóñez Barba, 2002). The Beveridge plan proposed "the construction of a system of social benefits that was able to protect citizens from the cradle to the grave and that attacked the five giant evils of modern societies: indigence, diseases, ignorance, dirt and idleness” (Ordóñez Barba, 2002, p. 109). Lastly, it included a unitary social security system for pensions, a national health service and a system of national assistance subsidies that also reached education and housing.

\section{Rise and decline of the welfare state: historical review and antecedents}

\subsection{Implementation of social welfare policies}

The generalisation in the application of social welfare policies led by state interventionism, under the aforementioned precedents, has increased since World War II in most European countries. The welfare state reached the institutional level surpassing the incipient residual level (Titmuss, 1950; cited after Alcock, 2001). After the end of the Second World War, strong economic growth in the so-called Western world was the main architect of the establishment and development of a welfare state financed through a steady increase in public spending and tax rates. The policies defined within the paradigms of the welfare state maintained a high degree of consensus once the war ended, with Great Britain being the main example of this new social order (Marshall, 1965). This consensus remained unbreakable until the effects of the so-called 1973 oil crisis. Logically, after a more than convulsive first half of the century, these policies represented an important source of pacification of social conflicts. The new mission of the welfare state is recognised as social responsibility on the part of the public powers of the state (Mishra, 1989). It is necessary to point out the importance of the end of the Second World War as a key moment. The reconstruction work was entrusted to the respective states, which meant a significant increase in state intervention in the economy. On the other hand, the victory over the armies of the axis was not only taken as a restoration of liberties, but it wanted to project itself as a new social order that would give rise to a more 
just and more egalitarian society. However, before this fact another crucial aspect was the economic crisis of 1929. In this way, as the Nobel Prize for Economics John Richard Hicks points out, after the stock market and economic crach caused by the Wall Strett crisis in 1929, there was almost generalised change of criteria on the need for state intervention in the economy. It can refer to the economic depression of 1929 as one of the inflection points of the increase of public powers in the respective economies (Montoro Romero, 2000). It was indeed after the Second World War when the previous expositions were revealed, scientifically covering them with the postulates of one of the most influential economists of the $20^{\text {th }}$ century, the British John Maynard Keynes. Although it is true that Keynes never came to refer to the concept of the welfare state in his work, his theories did in many cases serve as scientific support for the justification of the state's participation in the economy as a provider, among other things, of these welfare services (Furlani, 2009).

In summary, it can be noted that after the end of the Second World War, the political and social consequences of the war, together with the strong economic growth that occurred in the so-called Western world in the following years, were the main architects of the establishment and development of welfare services increasingly generous and universal. Therefore, this historical context was marked by a transfer of the private to the public, and by a common sense of consensus on the need to redistribute income in such a way that minimum living conditions are guaranteed to all citizens. From the crisis of 1973, the welfare state was not be able to avoid severe economic recessions and, even, the role of the state as an effective redistributor of the income was seriously put into question: the crisis that affected the welfare state was not only be of a financial nature, but also of legitimacy ${ }^{2}$.

2 The diagnosis of González Temprano and Torres Villanueva is illuminating: "the welfare state, although it is not the trigger of the economic crisis of 1973, does seem to have fed it through the growing deficit and public debt” (González Temprano and Torres Villanueva, 1992, p. 15). 


\subsection{Crisis of the welfare state and its causes}

The oil crisis of 1973 was an important point of inflection on the role of the state as an intervening agent in the economy of developed countries. Although the welfare state was not the trigger for this economic crisis, several authors do relate both realities (González Temprano and Torres Villanueva, 1992). Beyond previous conjunctural crises such as those of 1952, 1958-1959 and 1965-1967, the one of 1973 put into question the main reason used to justify state interventionism, including in this interventionism the management of the welfare state. The Keynesian approaches that justified the intervention of the state to counteract the economic cycles were questioned before its incapacity to maintain a sustained economic growth. In this way, the economist and keynesian James Tobin, in his work “How Dead is Keynes?” (1977) questioned to what extent these Keynesian approaches were dead. Other authors suggested in 1978 to save what was possible from the Keynesian shipwreck and recover what was profitable (Lucas and Sargent, 1978). A specific reference was usually made to this crisis of 1973, since it brought together a series of circumstances that questioned the bases, the approaches and the development model on which the traditional welfare state had been based, management of public welfare services. Indeed, after a period of great economic development, a new economic reality was revealed characterised by the tensions that could arise in the economy and, what is more important, that the hitherto sacrosanct state intervention could become incapable of remedying these economic tensions (Myles and Quadagno, 2002). The main aspects of this crisis are derived from the following reasons: the unlimited growth of the welfare state, the effect of increased fiscal pressure to finance the growing of the welfare state, and the moral risk derived from the tax increase and monopolistic provision of the state.

\subsection{The unlimited growth of the welfare state}

In 1973, the idea that the establishment of the welfare state (intended initially to endow developed societies with economic stability by guaranteeing minimum welfare services to all their members) had become a reality in a cause of concern for the different domestic economies. With the development and continuous increase of the 
demands in matters of social welfare "there is a progressive displacement of the functions of mere provision of public goods and services by the state towards essentially redistributive and assistance-type tasks” (González Páramo, 1994, p. 135). There is the assumption that the size of the welfare state will increase as its benefits increase and that will pass to a quasi-universal system of state responsibility for the lives of citizens. In this regard, it is interesting to recall Wagner's law, not because of his own assumptions about the advisability of public management over a private one or about the justification of state intervention in the economy, but because of the limitations that the German economist put to their own law and that are perfectly applicable to the current welfare state (Jaén García, 2004).

\subsection{The effect of increased fiscal pressure to finance the growing of the welfare state}

One of the main consequences refers to the effects derived from the fiscal pressure necessary to finance the welfare state, which, logically, will increase as its benefits increase and a quasi-universal system is introduced. This need for financing will be directly related to the broader tax wedge that citizens will have to endure. A high fiscal pressure destined to finance the welfare state not only does not serve as a stimulus for greater growth and economic efficiency, but it comes to suppose the exact opposite. That is, a danger to such efficiency and growth (Herce and Huerta de Soto, 2010). In short, as the American economist Arthur Laffer ${ }^{3}$ pointed out, based on certain levels of taxation, an increase in the tax rate does not entail an increase in tax collection.

${ }^{3}$ It is the famous Laffer curve. While it is true that these approaches had already been taken into consideration previously. Even in the fourteenth century, the North African Ibn Jandun already theorized about the relationships between these different economic concepts. 


\subsection{The moral risk derived from the tax increase and monopolistic provision of the state}

The existence of benefits that will be received by individuals whenever a certain level of income is not reached, or the existence of benefits that should be received in extraordinary situations, will cause many individuals to try to adjust their behaviour in order to receive said benefits. That is, situations may arise in which individuals will not work if the level of subsidies and benefits to the unemployed is high enough or that they will reduce their income so as not to lose the right to receive subsidies and benefits or to receive income that is fiscally opaque. This situation will be the cause of a permanent potential for imbalance (Buchanan, 1997). In the same way, we are faced with a monopolistic regime where there is little or no margin for competition, efficiency and decision-making power of individuals. To the own reasons of inefficiency that come derived from all monopolistic management we must add the derivatives of the application of political ideologies and electoral tensions. For this to not happen, it should be assumed that the public authorities have a level of efficiency and rigor in the management of resources that is greater than that of the individuals themselves or other private institutions. Contrary to what has happened in other sectors of the economy, in the case of the provision and production of welfare services, direct public management has continued to be maintained.

\section{Analysis of the case: Sweden 1989}

Sweden is often considered the role model of welfare policies. However, in the early nineties a reformulation of their welfare state was necessary to avoid its collapse. A period of strong recession, manifested in annual chanes in GDP (cf. Figure 1) had started Sweden in 1989, but had not recovered until well into the 1990s.

As the former Economy Minister and former Swedish Vice President Kjell-Olof Feldt pointed out, "our citizens - because of the Swedish population - were no longer able, nor willing, to bear the fiscal burden needed to keep the Welfare State going” (Feld, 1997, p. 58) The traditional support of welfare policies through increases in the tax burden came to an end because the population could 


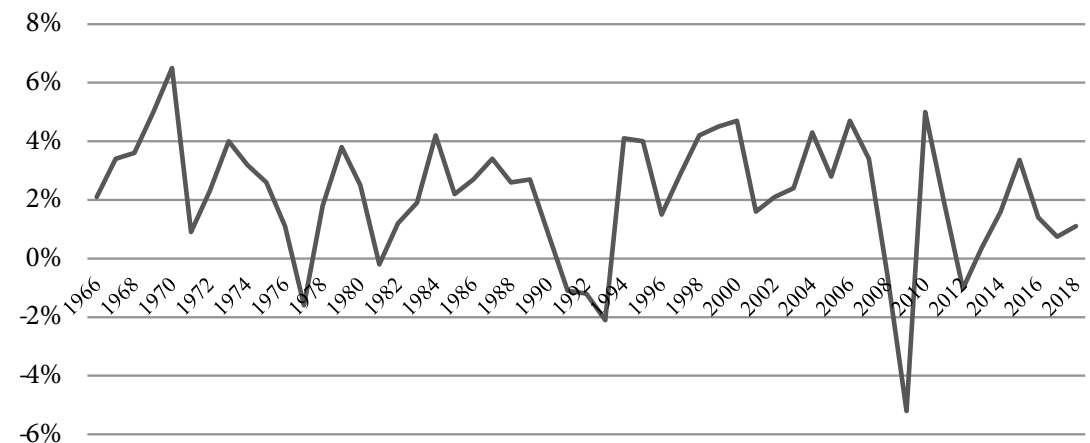

Figure 1. Annual change of GDP in Sweden [\%]

Source: Own elaboration based on data from Riksgälden (2008) and Eurostat.

not support higher tax rates, "the total tax burden doubled between 1960 and 1989, going from 28 to 56 percent of GDP” (Rojas, 1998, p. 29). Tax collection calculated as a percentage of GDP of Sweden in 1960-1989 is presented in Figure 2.

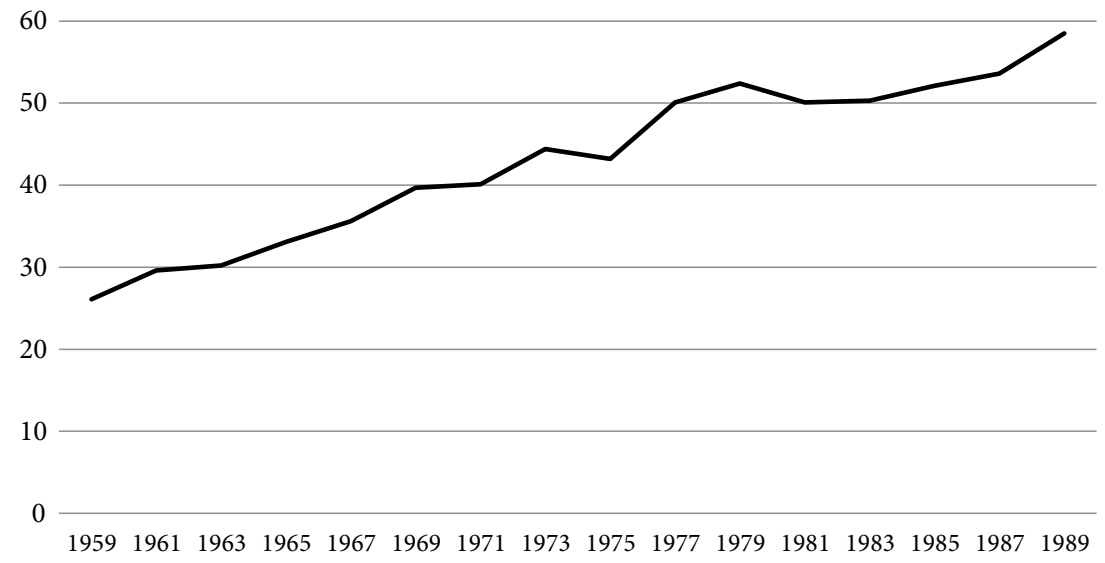

Figure 2. Tax collection in Sweden [\% of GDP] in 1960-1989

Source: Own elaboration based on data from Riksgälden (2008) and Eurostat.

This long period of economic contraction led to a considerable increase in the unemployment rate. Thus, as indicated in Figure 3, the unemployment rate moved up from two percent (situation of full employment) to a worrying thirteen percent in 1993. 


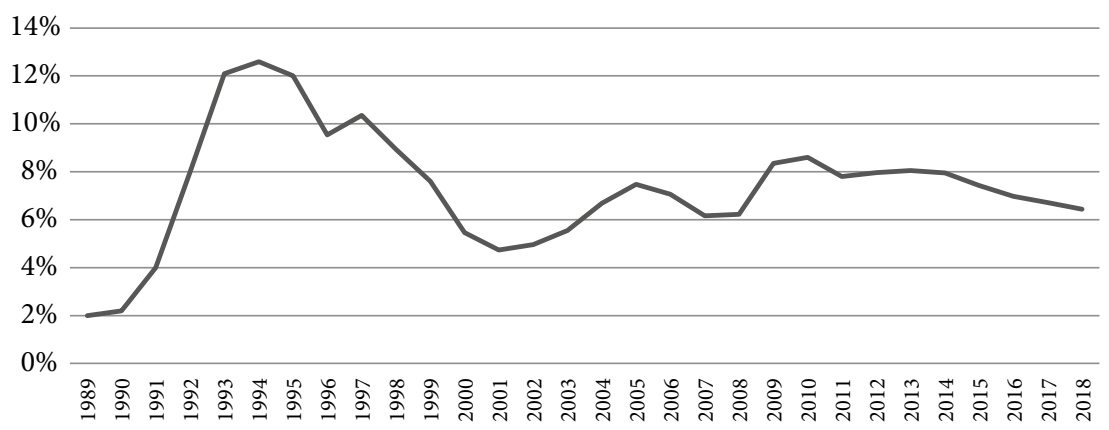

Figure 3. Unemployment rate in Sweden [\%]

Source: Own elaboration based on data from Riksgälden (2008) and Eurostat.

This growth in unemployment (which meant the loss of the job to more than 500,000 workers in the aforementioned period) led to a disproportionate increase in the spending of the public administration that passed, assuming 61\% of the Swedish GDP in 1990, until reaching, as shown in Figure 4, the unsustainable figure of $73 \%$ in 1993. The public deficit increased without end.

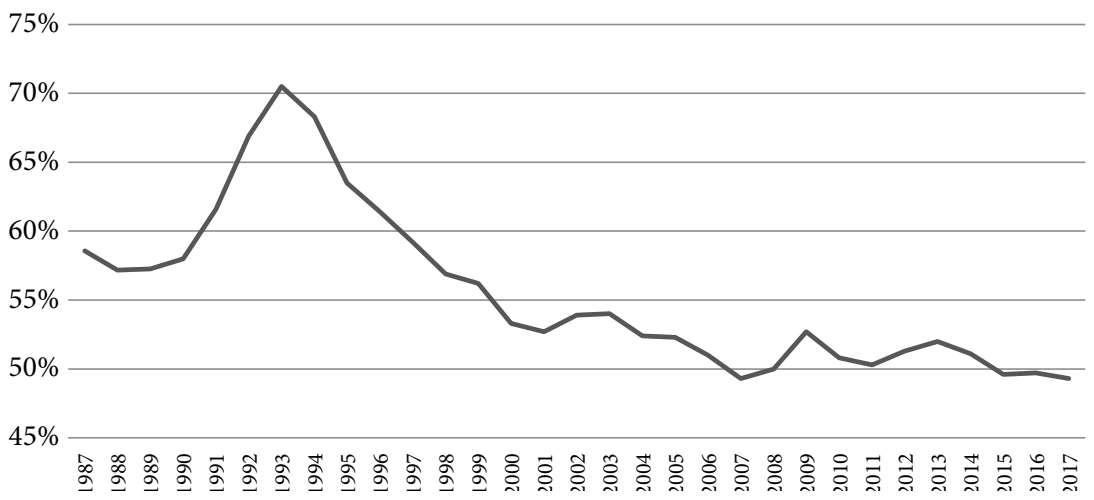

Figure 4. Percentage of expenditures of the Swedish Public Administration with respect to Sweden's GDP [\%]

Source: Own elaboration based on data from Riksgälden (2008) and Eurostat.

The direct consequence of the inability to defray expenses through income led to an unprecedented increase in the public deficit that reached $10.2 \%$ of the Gross Domestic Product in 1993. The 
indebtedness of the Swedish State was unsustainable. The level of public debt doubled between 1990 and 1994. The collapse of the Swedish economy was total, including the collapse of the exchange rate of the Swedish krona, which came to suppose that the Central Bank of Sweden offered interest rates of $500 \%$ to avoid its loss of value (Sánchez de la Cruz, 2011).

\section{Measures taken to correct the situation}

One of the consequences of the deep economic crisis suffered in Sweden at the beginning of the nineties of the last century, apart from the traditional policies of cuts, or abandonment of fixed exchange rates, was the development of a new model of management in the production of welfare services. Faced with an ineffective management of welfare services by Swedish public administration, the introduction of market criteria in the production of this type of services occurred. It was about "getting out of what was a closed planned economy to create a system of mixed well-being, based on the participation and collaboration of different actors: the state, the business community and citizens" (Rojas, 2008, p. 56). From the supply side, this change meant the opening to the private initiative of the public monopoly of production of welfare services. To break this traditional monopoly, a series of reforms were undertaken, ranging from the total or partial privatisation of important public companies, to the deregulation and generalisation of the bidding system within the public sector - i.e. freedom to open schools, health centers and many other activities whose demand is regulated either by the welfare voucher system or by direct payments of the fiscal system via bids (Rojas, 2008). From the side of the demand, these measures supposed an increase of the capacity of the citizens to choose the welfare services to receive. If until then every Swedish citizen had a public nursery, a public school or a public hospital, with the incorporation of private companies in the production of these services, citizens were allowed freedom of choice in their decisions to consume the services of wellness. The main exponent of this new model was the appearance of the so-called 'welfare vouchers'. From the operational side of the state, an attempt was made to safeguard the principle of equal opportunities in access to welfare services. Therefore, in this first 
profound reform, citizens were not given the possibility of extra payments in order to have priority access to certain services or to access services of a superior quality. This principle was well safeguarded by direct public financing - the production of these services had to comply with the requirements and conditions imposed by the administration; or, for indirect public financing, through the system of public vouchers to the consumer that had freedom to decide on the choice of the service provider.

The modernisation of the Swedish Welfare State was based on a replacement of the traditional model with a new enabling system. This new enabling system allowed the creation of a competitive market in the production of services linked to well-being. This opening in the production of services did not mean the disappearance of private providers. In fact, the new providers of welfare services were both private and public initiative. Thus, the American economist and Nobel laureate James Buchanan, referred to the changes introduced in the traditional way of producing welfare services in Sweden, noting that "there is no more model than the Swedish model” (Buchanan, 1997, p. 36).

\section{Conclusions}

Based on what has been analysed, it is appropriate to refer to the welfare state as a set of public actions aimed at guaranteeing minimum levels of quality of life and well-being to the entire population, regardless of the public or private nature of the provider of the services.

The events that took place in this Nordic country in the early 1990s place Sweden as one of the most interesting and recurring examples of reformulation of the welfare state to ensure its sustainability. The emergence of this welfare capitalism, to which the public or semi-public producers who continued to deliver these services must have joined, resulted in a significant decrease in state production costs, while maintaining the level of assistance.

That is, the opening of the market caused an increase in its competitiveness, resulting in a more efficient and effective management, capable of offering more attractive services at lower costs. The previous definition implies the control and public supervision 
of compliance with these minimum levels of quality of life and well-being in the best conditions of efficiency and quality. That is, the best social protection system for society should be dictated by its results and its economic efficiency, regardless of whether these services are offered from a public dimension.

With this new approach, the traditional function of the welfare state and social protection would remain absolutely valid, but there is a need to assess its current management to check whether these prerequisites for efficiency and effectiveness are being met. That is, it must be guaranteed that the production of these services aimed at the welfare of the population is carried out by those agents who can offer them in the most efficient way possible, even if the public authorities retain the provision and supervision of them.

Although each country and each model have their own characteristics, different authors influence the possibility of "no longer the copy of the model, impossible because of the specificities of each country, but their virtues in terms of their active policies, the reconciliation of security and flexibility or the renewal of the social protection system” (Urteaga, 2013, p. 157).

In this way, the present work provides a new delimitation in the existing classifications on the concept of the welfare state characterised by a strong participation of public authorities in the establishment of social protection programs, but in which private and social initiatives play a fundamental role. Thus, to the traditional concepts of authors such as Titmuss, Libeux and Wilensky or Esping Andersen, which defined a series of residual or institutional models depending on the intensity of state intervention in matters of social protection, a new dimension is incorporated with this work. These approaches are totally necessary when referring to the crisis of legitimacy in the precepts of the traditional welfare state. In this way, this research is encompassed within the so-called welfare pluralism that advocates introducing civil society in the production of welfare services, maintaining the provision and public control of the system. The consequences of this management change, apart from the economic effects produced by the foreseeable increase in the efficiency and competitiveness of the new system, would be to return responsibility and initiative to civil society, moving from a welfare state or a state enabler.

Nowadays, as several specialized sources point out, thanks to the changes in the management of these welfare services and the 
adjustment made by the public sector, "Sweden is an example in the provision of public services granted to the private sector in orderly, transparent and controlled form” (Woodbridge, 2018, p. 1).

\section{References}

Alcock, P. (2001), Welfare and Wellbeing: Richard Titmuss's Contribution to Social Policy, The Policy Prees, Bristol.

Beveridge, W.H. (1909), Unemployment: A Problem of Industry, Longmans Green, London.

Beveridge, W.H. (1944), Full Employment in a Free Society, George Allen and Unwin, London.

Buchanan, J. (1997), “Democracia mayoritaria y bienestar general”, in: El Estado del Bienestar a Examen: Un reto para el sector privado, X Conferencia Internacional de Asociaciones Empresariales Privadas, Madrid, 28-29 de octubre 1996, Círculo de Empresarios, Madrid, pp. 35-55.

Domingo Solans, E. (1998), "Replanteamiento de la forma de actuar del Estado en economía”, in: Fernández-Miranda y Lozana. E. (Ed.), Sostenibilidad del Estado del Bienestar en España, Price Waterhouse, Madrid, pp. 9-34.

Feld, K. (1997), “La revision del Estado del Bienestar: El dilema sueco”, in: El Estado del Bienestar a Examen: Un reto para el sector privado, X Conferencia Internacional de Asociaciones Empresariales Privadas, Madrid, 28-29 de octubre 1996, Círculo de Empresarios, Madrid, pp. 57-71.

Furlani, M. (2009), “El Estado del Bienestar: Auge y resquebrajamiento”, Revista Electrónica de Psicología Política, Vol. 7, No. 20, pp. 42-51.

González Temprano, A., Torres Villanueva, E. (1992), El estado del bienestar en los países de la OCDE, Centro Publicaciones Ministerio de Trabajo y Seguridad Social, Madrid.

González Páramo, J.M. (1994), “Gasto social y crecimiento económico en el Estado del Bienestar”, Hacienda Pública Española, No. 2, pp. 135-153.

Hayek, F.A. (1946), Der Weg zur Knechtschaft, Eugen Rentsch, Erlenbach-Zürich.

Herce, J.A., Huerta de Soto, J. (2010), Perspectivas del Estado del Bienestar: Devolver responsabilidad a los individuos, aumentar las opciones, Fundación para el Análisis y los Estudios Sociales, Madrid.

Jaén García, M. (2004), La Ley de Wagner: Un análisis sintético, Papeles de trabajo, Instituto de Estudios Fiscales, Madrid.

Jiménez Franco, E. (2000), "El estado del bienestar: Orígenes, alternativas y perspectivas”, in: Escobar, C., Sánchez G. (Eds.), El trabajo social en la era de la incertidumbre, Actas del I Congreso de estudiantes de Trabajo Social, Salamanca el 26 y 27 de noviembre 1999, pp. 55-72.

Kendall, J., Knapp, M. (2000), The Third Sector and Welfare State Modernisation: Inputs, Activities and Comparative Performance, Civil Society Working Paper 14, Centre for Civil Society, London School of Economics, London.

Lucas, R., Sargent, T.J. (1978), “After Keynesian Macroeconomics”, in: The Federal Reserve Bank of Boston, After the Phillips Curve: Persistence of High 
Inflation and High Unemployment, Conference Series, Proceedings of a Conference held at Edgartown, Massachusetts, pp. 49-71.

Martínez Girón, J. (2001), “La etapa de previsión social en España”, Annuario da Facultade de Dereito da Universisade da Coruña, No. 5, pp. 431-442.

Marshall, T.H. (1965), Social Policy, Hutchinson University Library, London.

Mishra, R. (1989), "El estado del bienestar después de la crisis: Los años ochenta y más allá”, in: Muñoz de Bustillo Llorente, R. (Ed.), Crisis y futuro del estado del bienestar, Alianza, Madrid, pp. 5-80.

Mommsen, W. (1996), Otto von Bismark, Rowohlt Taschenbuch Verlag, Reinback bei Hamburg.

Montoro Romero, R. (2000), “El Estado del Bienestar moderno”, in: Muñoz Machado, S., García Delgado, J.L., González Seara, L. (Eds.), Las estructuras del bienestar en Europa, Fundación ONCE-Civitas, pp. 131-182.

Muñoz Machado, S., García Delgado, J.L., González Seara, L. (1997), Las estructuras del bienestar: Derecho, economía y sociedad en España, Editorial Civitas, Madrid.

Myles, J., Quadagno, J. (2002), “Political Theories of the Welfare State”, Social Service Review, Vol. 76, No. 1, pp. 34-57.

Offe, C. (2007), "Democracia competitiva de partidos y Estado de Bienestar keynesiano: Reflexiones acerca de sus limitaciones históricas”, in: Lecturas sobre el Estado y las políticas públicas: Retomando el debate de ayer para fortalecer el actual, Proyecto de Modernización del Estado, Jefatura de Gabinete de Ministros de la Nación, Buenos Aires, pp. 101-114.

Ordóñez Barba, G. (2002), "El Estado de bienestar en las democracias occidentales: Lecciones para analizar el caso mexicano”, Región y Sociedad, Vol. XIV, No. 24, pp. 99-145.

Rojas, M. (2008), Reinventar el estado del bienestar, Editorial Fundación FAES S.L.U., Madrid.

Rosete, A.Á. (2004), “i Bienvenido, Mister Beveridge! El viaje de William Beveridge a España y la Previsión Social Franquista”, International Journal of Iberian Studies, Vol. 17, No. 2, pp. 105-116.

Sánchez de la Cruz, D. (2011), "El mito sueco”. Retrieved from http://diego-sanchezde-la-cruz.libremercado.com/2011/11/02/el-mito-sueco/ (accesed 13 November 2018).

Social Security Administration (2015), "Breve historia de seguro social”, Social Security Administration, United States Government. Retrieved from http://www.ssa.gov/ espanol/brevehistoria.htm (accessed 10 October 2018).

Titmuss, R.M. (1950), Problems of Social Policy, H.M. Stationary Office, London.

Tobin, J. (1977), “How Dead is Keynes?”, Economic Inquiry, Vol. 15, Issue 4, pp. 459-468.

Urteaga, E. (2013), “Transformación del Estado del Bienestar e inversión social”, Revista de Investigaciones Políticas y Sociológicas, Vol. 12, No. 1, pp. 157-174.

Woodbridge, J. (2018), “El modelo sueco”. Retrieved from https://www.nacion.com/ opinion/foros/el-modelo-sueco/BWDL2TM5TNC3FLZQFUC7PHJRH4/story/ (accessed 01 September 2018). 
